Article

\title{
Sensitivity Assessment of Varieties, Effectiveness of Weed Control by Selected Herbicides, and Infection of the Fusarium in Maize (Zea mays L.) Cultivation
}

\author{
Małgorzata Jagła $^{1}$, Łukasz Sobiech ${ }^{1, *(\mathbb{D})}$, Piotr Szulc ${ }^{1}{ }^{1}$, Kamila Nowosad ${ }^{2}$, Jan Bocianowski ${ }^{3 \oplus}$ \\ and Monika Grzanka ${ }^{1}$ (D) \\ 1 Department of Agronomy, Poznan University of Life Sciences, 60-637 Poznan, Poland; \\ malgorzata.jagla@up.poznan.pl (M.J.); piotr.szulc@up.poznan.pl (P.S.); \\ monika.grzanka@up.poznan.pl (M.G.) \\ 2 Department of Genetics, Plant Breeding and Seed Production, Wrocław University of Environmental and \\ Life Sciences, Grunwaldzki 24A, 53-363 Wrocław, Poland; kamila.nowosad@upwr.edu.pl \\ 3 Department of Mathematical and Statistical Methods, Poznań University of Life Sciences, \\ 60-637 Poznań, Poland; jan.bocianowski@up.poznan.pl \\ * Correspondence: lukasz.sobiech@up.poznan.pl
}

Received: 12 June 2020; Accepted: 30 July 2020; Published: 1 August 2020

\begin{abstract}
The amount of maize yield depends on many factors. Among them, plant health plays a significant role. Herbicide selectivity (of mesotrione, 2,4-D, and bromoxynil) for different maize varieties was assessed in greenhouse experiments. The effectiveness of herbicides (MCPA, 2,4-D + dicamba) and spraying mixture of the herbicide MCPA with mepiquat chloride was tested on Chenopodium album L. and self-seeding winter oilseed rape (Brassica napus L.). The genetic distance between selected maize varieties and species composition of pathogens of the genus Fusarium isolated from the seeds of the discussed crop were examined. Research results indicated that individual herbicides differed in the selectivity in relation to maize, which depended on the crop variety. The selected herbicides showed high efficacy against the plants used in the experiment. The addition of mepiquat chloride to the composition of the spraying liquid did not affect the level of weed control. No relationship was found between the genetic distance of maize varieties and their sensitivity to selected herbicides. The presence of Fusarium subglutinans, Fusarium proliferatum, and Fusarium verticillioides was found in the samples of maize varieties.
\end{abstract}

Keywords: Zea mays L.; herbicide; efficacy; selectivity; Chenopodium album L.; Brassica napus L.

\section{Introduction}

The application of herbicides is considered the most cost-effective method of weed control in developed countries [1]. Herbicides may, however, contribute to phytotoxic effects in a crop [2]. It is necessary to study the selectivity of these preparations in relation to different varieties, because intraspecific genetic distinctiveness can contribute to a different reaction of plants to individual substances [3]. Damage to plants by herbicides may make them more susceptible to infestation by diseases.

Synthetic auxin herbicides affect the increased regulation of auxins in plants, leading to disruption of the balance of natural plant growth hormones, which impair and differentiate normal growth and cause abnormal uncontrolled cell division and uncontrolled growth and damage to chloroplasts, membranes, and vascular tissues [4]. Synthetic auxin herbicides such as 2,4-D and dicamba are important systemic herbicides in the control of dicotyledonous weeds $[5,6]$.

Mesotrione is a substance that belongs to the inhibitors of the $>$-hydroxyphenylpyruvate dioxygenase (HPPD) enzyme [7]. HPPD participates in the transformation of tyrosine into plastoquinone and 
tocopherol [8]. As a result of blocking the enzyme by the herbicide, the synthesis of carotenoids is disturbed, which leads to chlorophyll degradation [9]. The action of these substances is manifested by plant whitening. Herbicides containing the above substance are intended to control dicotyledonous and monocotyledonous weeds in maize plantations [10].

Bromoxynil is an active substance classified as an inhibitor of photosystem II [11]. The mechanism of action of this group of herbicides is based on binding a protein that should be bound to plastoquinone $\mathrm{Q}_{b}$. The flow of electrons from plastoquinone $\mathrm{Q}_{\mathrm{a}}$ to plastoquinone $\mathrm{Q}_{\mathrm{b}}$ is prevented as a result of blocking the protein, and, as a consequence, the photosynthesis. Plant chlorosis and necrosis are the symptoms of the effects of substances belonging to photosystem II inhibitors [12].

The use of mepiquat chloride increases the physical strength of the stems, which is manifested by increased periderm puncture force, stem bending strength, increased dry matter density per $\mathrm{cm}$, stem diameter, and lignin accumulation [13]. Mepiquat chloride spraying procedure significantly affects plant height, leaf area index (LAI), dry matter production (DMP), and baby corn yield [14]. Currently, the combined use of agrochemicals, including herbicides with growth regulators, is becoming an increasingly frequent practice [15]. However, research on the effectiveness of combined protection agents and their phytotoxicity to crops is necessary.

In turn, pathogens of the genus Fusarium infect many plant species around the world, including maize. They contribute to decreased yield quality and quantity [16]. Contamination of harvest with mycotoxins, which are dangerous to human and animal health, is a major problem associated with the occurrence of pathogens of this type [17].

The aim of the study was to assess selected factors affecting the health status of different maize varieties and the effectiveness of controlling the weeds occurring in this cultivation. Herbicide selectivity for different maize varieties was evaluated. The effectiveness of herbicides and spraying mixture of the herbicide with mepiquat chloride was tested on Chenopodium album L. and self-seeding winter oilseed rape (Brassica napus L.). The genetic distance between selected maize varieties and species composition of pathogens of the genus Fusarium isolated from the seeds of the discussed crop were also the aims of the study.

\section{Materials and Methods}

\subsection{Greenhouse Experiments}

Greenhouse studies were conducted at the Department of Agronomy at the Poznań University of Life Sciences, based on two experiments. In each experiment, plants were sown into $0.7 \mathrm{~L}$ pots containing a sterile commercial soil mix with the addition of macroelements and microelements (specification: pH 5.5-6.5; $\mathrm{NaCl} 1.9 \mathrm{~g} \mathrm{NaCl} / \mathrm{dm}^{3}$; NPK $\left.+\mathrm{Mg}-(14-16-18+5) 0.8 \mathrm{~kg} / \mathrm{dm}^{3}\right)$. The pots were subsequently placed in the greenhouse at $26^{\circ} \mathrm{C}\left( \pm 4^{\circ} \mathrm{C}\right) / 19^{\circ} \mathrm{C}\left( \pm 4^{\circ} \mathrm{C}\right)$ day/night without additional artificial lighting. The relative air humidity was maintained at 50 to $80 \%$. Substrate condition was monitored daily so that the humidity oscillated around $70 \%$ of the full water capacity. Water shortages were supplemented with tap water, if necessary. The spraying procedure was performed at the BBCH 13-14 stage (i.e., in the developmental phase of 3-4 leaves); the control sample was not sprayed. Four replicates were performed in a completely random order in two experimental series. The treatments were carried out using a laboratory sprayer equipped with a set of TeeJet flat spray tips, type DGTJ60 11003, with a capacity of $300 \mathrm{~L} / \mathrm{ha}$, at an operating pressure of $0.3 \mathrm{MPa}$. The sprayers were located at a height of $50 \mathrm{~cm}$ above the plants.

\subsubsection{Experiment I}

The experiment concerned the assessment of herbicide selectivity for maize (Zea mays L.)—traditional and "stay green" varieties. Fodder maize (Zea mays L.) cultivated for grain, widely available on the market, was selected for the experiment. According to the EPPO methodology (PP 1/50(3)), a double recommended dose was used in herbicide phytotoxicity studies. The assessment of crop 
susceptibility to herbicides was carried out 7, 14, and 21 days after treatment (DAT) by determining the damages (chlorosis, necrosis, stunting, torsion). The assessment consisted of visual estimation of the occurrence of morphological changes of the crop in relation to control, according to a scale from $0-100 \%$, where $0 \%$-no damage and $100 \%$-complete destruction.

Stage a-32 maize varieties, whose breeders were Syngenta Polska Sp. z o.o., and Limagrain Central Europe served as the experimental material. This experiment tested the selectivity of a plant protection product containing mesotrione (Callisto 100 SC, Syngenta Polska Sp. z o.o. Warsaw Poland) compared to test plants. The herbicide was used at a dose of $3 \mathrm{~L}^{*} \mathrm{ha}^{-1}=300 \mathrm{~g}$ s.a. ${ }^{*} \mathrm{ha}^{-1}$.

Stage $b-12$ maize varieties bred by Limagrain Central Europe were selected for testing. In this experiment, the selectivity of herbicides containing 2,4-D (Esteron 600 EC, Dow AgroSciences Polska Sp. z o.o. Warsaw Poland) was tested at a dose of $2 \mathrm{~L}^{*} \mathrm{ha}^{-1}=1200 \mathrm{~g}$ s.a. ${ }^{*} \mathrm{ha}^{-1}$, and bromoxynil (Bromotril 250 SC, Adama Polska Sp. z o.o Warsaw Poland.), at a dose of $2 \mathrm{~L}^{*} \mathrm{ha}^{-1}=350 \mathrm{~g}$ s.a. ${ }^{*} \mathrm{ha}^{-1}$, was tested in comparison to test plants.

\subsubsection{Experiment II}

Based on the analysis of the results carried out in experiment I, two maize varieties were selected for further research: traditional SY Cooky FAO 220-230 and "stay green" NK Ravello FAO 210. The selection of these varieties allowed comparison reaction of traditional and stay green varieties to herbicides. The breeder of both varieties was Syngenta Polska Sp. z o.o. The selected varieties did not show morphological changes in reaction to the applied herbicides with a different mechanism of action. The study used the herbicides given in Table 1 .

Table 1. Herbicides applied in experiment II and III.

\begin{tabular}{cccccc}
\hline No. & Plant Protection Products & Producer & Active Ingredient & Dose (L/ha) & Dose (g a.i./ha) \\
\hline 1 & Chwastox Extra 300 SL & $\begin{array}{c}\text { CIECH Sarzyna S.A., } \\
\text { Poland }\end{array}$ & MCPA (300 g/L) & 3 & 900 \\
\hline 2 & $\begin{array}{c}\text { Chwastox Extra 300 SL }+ \\
\text { Mepik 300 SL }\end{array}$ & $\begin{array}{c}\text { CIECH Sarzyna S.A., } \\
\text { Polska + Innvigo Sp. z o.o., } \\
\text { Poland }\end{array}$ & $\begin{array}{c}\text { MCPA (300 g/L) + } \\
\text { mepiquat chloride } \\
(300 \mathrm{~g} / \mathrm{L})\end{array}$ & $3+1.3$ & $900+390$ \\
\hline 3 & $\begin{array}{c}\text { Aminopielik Standard } \\
\text { 600 SL + Dicash }\end{array}$ & $\begin{array}{c}\text { ADAMA Manufacturing } \\
\text { Poland S.A. + Sharda } \\
\text { Europe b.v.b.a., Kingdom } \\
\text { of Belgium }\end{array}$ & $\begin{array}{c}2,4-\mathrm{D}(600 \mathrm{~g} / \mathrm{L})+ \\
\text { dicamba }(480 \mathrm{~g} / \mathrm{L})\end{array}$ & $0.5+0.5$ & $300+240$ \\
\hline
\end{tabular}

\subsubsection{Experiment III}

The experiment concerned the evaluation of the effectiveness of selected herbicides from the group of growth regulators against two weed species: Chenopodium album L. and self-seeding winter oilseed rape (Brassica napus L.). Evaluation of the effectiveness of tested preparations was carried out 14 days after spraying. The effectiveness of the agents was evaluated visually in relation to the control (without spraying), according to a $0-100 \%$ scale, where $0 \%$-no effectiveness and $100 \%$-full effectiveness. The study used the herbicides given in Table 1.

\subsection{Laboratory Experiments}

\subsubsection{Methodology—Genetic Similarity of Varieties}

A sample of $0.1 \mathrm{~g}$ fresh young tissues was collected from each cultivar and ground into a fine powder, using liquid nitrogen in the TissueLyser II system (Qiagen, Hilden, Germany). Total genomic DNA was extracted using a commercially available DNA extraction kit (DNeasy Plant Mini Kit, Qiagen, Hilden, Germany), following the manufacturer's instructions. DNA was quantified using a Picodrop Microliter UV/Vis Spectrophotometer (Saffron Walden, United Kingdom, London). The PCR was run in a TProfessional thermocycler (Biometra, Jena, Germany), using a set of 30 simple sequence repeat (SSR) 
primers [18]. 100 pairs of primers were tested in a preliminary experiment. On the basis of results of this experiment, we selected 30 SSR primers. Sequences of all tested primers came from a database [19]. The PCR reaction mix $(15 \mu \mathrm{L})$ included the following: $70 \mathrm{ng}$ genomic DNA, $100 \mu \mathrm{M}$ each dNTP, $0.2 \mu \mathrm{M}$ forward and reverse primers, $1 \mathrm{x}$ Taq polymerase buffer, and $2 \mathrm{U}$ Tag polymerase (Thermo, Waltham, USA). Amplifications were carried out for 35 cycles, each consisting of a denaturation step of $40 \mathrm{~s}$ at $95^{\circ} \mathrm{C}$, followed by an annealing step of $30 \mathrm{~s}$ at $55^{\circ} \mathrm{C}$ and an extension step of $1 \mathrm{~min}$ at $72{ }^{\circ} \mathrm{C}$, with a final extension at $72{ }^{\circ} \mathrm{C}$ for $7 \mathrm{~min}$. The amplified products were analyzed on the QIAxcel system with the QIAxcel HighResolution Kit (Qiagen, Hilden, Germany)following the AM420 method. The five cultivars (NK Cooler, Delitop, NK Ravello, SY Cooky, and Drim) were scored for the presence and absence of the SSR bands. Data were entered into a binary matrix as discrete variables, with " 1 " for the presence and " 0 " for the absence of alleles. Genetic similarity (GS) for each pair of cultivars was estimated, based on the coefficient proposed by Nei and Li (1979) [20], defined as GS = 2NAB/(NA $+N B$ ), where NAB is the number of bands shared by cultivars $A$ and $B, N A$ is the number of bands in cultivar A, and NB is the number of bands in cultivar B. The cultivars were grouped using the unweighted pair group method with arithmetic mean (UPGMA). Similarities between cultivars were visualized on a dendrogram.

\subsubsection{Identification of Fusarium Species}

We ensured that 200 maize seeds of each sample were surface-sterilized for 1 min with $1 \%$ sodium hypochlorite solution, rinsed twice in sterile distilled water, and dried in a laminar flow cabinet. Two growth media, i.e., potato dextrose agar (PDA) and peptone PCNB agar, were used for fungal isolation. The plates were incubated at $25^{\circ} \mathrm{C}$ in the dark for 5-7 days. Using a single spore technique [21], all Fusarium isolates were subcultured on PDA, Spezieller Nahrstoffarmer Agar (SNA), and carnation leaf agar (CLA). PDA cultures were incubated at $25^{\circ} \mathrm{C}$, and CLA and SNA cultures were incubated at $25^{\circ} \mathrm{C}$ under near UV light for two to four weeks. Cultural characteristics were visually assessed as well as by microscopic examination. We recorded the morphology of the colony from cultures grown on PDA. The morphology of macroconidia, microconidia, conidiogenous cells, and the chlamydospores was assessed from cultures grown on SNA and CLA. The morphological identifications of isolates were completed using the criteria of Gerlach and Nirenberg [22] and Leslie and Summerell [21].

\section{DNA extraction}

Fusarium isolates were grown on PDA plates for seven days, and mycelia were harvested and ground in liquid nitrogen. Total DNA was extracted from ground mycelium of each isolate ( $\sim 100 \mathrm{mg}$ wet weight) using a DNeasy Plant Mini Kit (Qiagen, Hilden, Germany), according to the manufacturer's instructions.

\section{Species-specific PCR}

The primer pairs VER1/2, PRO1/2, and SUB1/2 were used in species-specific PCR assays to identify F. verticillioides, F. proliferatum, and F. subglutinans, respectively [23]. The reaction mixtures were prepared in a total volume of $25 \mu \mathrm{L}$ with a final concentration of $50 \mathrm{mM} \mathrm{KCl}, 10 \mathrm{mM}$ Tris- $\mathrm{HCl}$ (pH 8.3), $0.2 \mathrm{mM}$ of each dNTP, and $1.5 \mathrm{mM} \mathrm{MgCl}_{2}$. For each reaction, $0.6 \mathrm{U}$ of Ampli Taq polymerase (Applied Biosystems, Foster City, USA), 15 pmol of each primer, and approximately 25 ng of fungal template DNA were used. Reactions were performed in a GeneAmp ${ }^{\circledR}$ PCR system 9700 thermal cycler (Applied Biosystems, USA), using the following PCR conditions: denaturation at $95^{\circ} \mathrm{C}$ for $5 \mathrm{~min}$, 35 cycles of denaturation at $94{ }^{\circ} \mathrm{C}$ for $50 \mathrm{~s}$, annealing at $56^{\circ} \mathrm{C}$ for $50 \mathrm{~s}$, extension at $72{ }^{\circ} \mathrm{C}$ for $1 \mathrm{~min}$, and final extension at $72{ }^{\circ} \mathrm{C}$ for $7 \mathrm{~min}$, followed by cooling at $4{ }^{\circ} \mathrm{C}$ until the samples were recovered. The amplification products were visualized in $1.2 \%$ agarose gels stained with ethidium bromide [23]. 


\subsection{Statistical Analysis}

In all experiments, statistical evaluation of the results was carried out using analysis of variance for orthogonal factorial experiments in the Agriculture Research Manager 8.0 software. The significance of result diversification was assessed by the Fisher-Snedecor test at the significance level of 0.05 , while the significance of differences between means was based on the Student-Newman-Keuls test.

\section{Results}

\subsection{Greenhouse Experiments}

\subsubsection{Experiment I}

The examined varieties of maize grown for grain reacted differently to the protection variants. The varieties Kardona, SY Multitop, and Laureen showed the highest sensitivity to the active substance mesotrione in experiments on the phytotoxicity of standard herbicide preparations. The preparation Esteron 600 EC containing the active substance 2,4-D 2-EHE in the form of an ester-a compound from the group of phenoxy acids—caused damage in all maize varieties. The largest damage was recorded in the varieties Laureen, GSS 5829, GSS 8529, Overland, and Golda. Maize varieties showed high tolerance to the herbicide Bromotril 250 SC containing the active substance-bromoxynil. Morphological changes were found in the varieties LG 30.275 and Laureen. The results are shown in Tables 2-5.

Table 2. Sensitivity of maize varieties to the herbicide Callisto 100 SC (mesotrione)—varieties bred by Syngenta Polska Sp. z o.o.

\begin{tabular}{|c|c|c|c|c|}
\hline \multicolumn{5}{|c|}{ Phytotoxicity (\%) } \\
\hline \multirow{2}{*}{ No. } & \multirow{2}{*}{ Variety } & \multicolumn{3}{|c|}{ Callisto $3.0 \mathrm{~L} / \mathrm{ha}$} \\
\hline & & 7 DAT & 14 DAT & 21 DAT \\
\hline 2 & NK Jasmic & 0 & 0 & 0 \\
\hline 3 & NK Ravello SG & 0 & 0 & 0 \\
\hline 4 & Exapic & 3 & 4 & 0 \\
\hline 5 & Drim SG & 0 & 0 & 0 \\
\hline 6 & SY Cooky & 0 & 0 & 0 \\
\hline 7 & Delitop SG & 6 & 6 & 0 \\
\hline 8 & NK Cooler SG & 4 & 3 & 0 \\
\hline 9 & SY Contract & 11 & 10 & 0 \\
\hline 10 & SY Multitop & 11 & 12 & 0 \\
\hline 11 & SY Consistent SG & 0 & 0 & 0 \\
\hline 12 & Arobase & 10 & 6 & 0 \\
\hline 13 & NK Nekta SG & 6 & 6 & 0 \\
\hline 14 & SY Counter SG & 1 & 1 & 0 \\
\hline 15 & SY Enigma & 0 & 1 & 0 \\
\hline 16 & Nebora & 9 & 6 & 0 \\
\hline 17 & NK Magitop SG & 3 & 3 & 0 \\
\hline 18 & SY Ondina SG & 0 & 0 & 0 \\
\hline 19 & Longitop & 3 & 3 & 0 \\
\hline 20 & Kardona & 13 & 9 & 0 \\
\hline 21 & Kaivo & 0 & 0 & 0 \\
\hline & $\operatorname{LSD}_{0.05}$ & 4.7 & 5.1 & 0.0 \\
\hline
\end{tabular}


Table 3. Sensitivity of maize varieties to the herbicide Callisto 100 SC (mesotrione) varieties bred by Limagrain Central Europe.

\begin{tabular}{ccccc}
\hline \multicolumn{5}{c}{ Phytotoxicity (\%) } \\
\hline \multirow{2}{*}{ No. } & Variety & \multicolumn{4}{c}{ Callisto 3.0 L/ha } \\
\cline { 3 - 5 } & & 7 DAT & 14 DAT & 21 DAT \\
\hline 2 & LG 30.260 SG & 5 & 8 & 0 \\
\hline 3 & LG 30.240 & 3 & 1 & 0 \\
\hline 4 & LG 32.16 & 2 & 6 & 0 \\
\hline 5 & LG 30.275 SG & 0 & 1 & 0 \\
\hline 6 & LG 32.32 & 2 & 6 & 0 \\
\hline 7 & LG 22.44 & 8 & 9 & 0 \\
\hline 8 & LG 32.15 & 16 & 12 & 0 \\
\hline 9 & LG 22.43 & 9 & 11 & 0 \\
\hline 10 & LG 32.52 & 13 & 8 & 0 \\
\hline 11 & LG 30.238 & 2 & 0 & 0 \\
\hline 12 & LG 32.58 & 4 & 1 & 0 \\
\hline 13 & Laureen & 21 & 15 & 0 \\
\hline & LSD 0.05 & 5.3 & 6.2 & 0.0 \\
\hline
\end{tabular}

note: SG—stay green.

Table 4. Sensitivity of maize varieties to the herbicide Esteron 600 EC (2,4-D).

\begin{tabular}{ccccc}
\hline \multirow{5}{*}{ No. } & \multirow{3}{*}{ Phytotoxicity (\%) } \\
\cline { 3 - 5 } & & \multicolumn{3}{c}{ Esteron 2.0 L/ha } \\
\hline 2 & LG 30.260 SG & 10 & 15 & 0 \\
\hline 3 & LG 30.240 & 10 & 15 & 0 \\
\hline 4 & LG 32.16 & 10 & 11 & 0 \\
\hline 5 & LG 30.275 SG & 10 & 9 & 0 \\
\hline 6 & LG 32.32 & 8 & 8 & 0 \\
\hline 7 & LG 22.44 & 5 & 8 & 0 \\
\hline 8 & LG 32.15 & 10 & 8 & 0 \\
\hline 9 & LG 22.43 & 10 & 13 & 0 \\
\hline 10 & LG 32.52 & 1 & 2 & 0 \\
\hline 11 & LG 30.238 & 0 & 2 & 0 \\
\hline 12 & LG 32.58 & 10 & 8 & 0 \\
\hline 13 & Laureen & 18 & 20 & 0 \\
\hline & LSD 0.05 & 1 & 1.9 & 0.0 \\
\hline & & note: SG-stay green. & \\
\hline
\end{tabular}


Table 5. Sensitivity of maize varieties to the herbicide Bromotril 250 SC (bromoxynil).

\begin{tabular}{ccccc}
\hline \multicolumn{5}{c}{ Phytotoxicity (\%) } \\
\hline \multirow{2}{*}{ No. } & Variety & \multicolumn{3}{c}{ Bromotril 2.0 1/ha } \\
\cline { 3 - 5 } & & 7 DAT & 14 DAT & 21 DAT \\
\hline 2 & LG 30.260 SG & 0 & 0 & 0 \\
\hline 3 & LG 30.240 & 0 & 0 & 0 \\
\hline 4 & LG 32.16 & 0 & 0 & 0 \\
\hline 5 & LG 30.275 SG & 5 & 0 & 0 \\
\hline 6 & LG 32.32 & 0 & 0 & 0 \\
\hline 7 & LG 22.44 & 0 & 0 & 0 \\
\hline 8 & LG 32.15 & 0 & 0 & 0 \\
\hline 9 & LG 22.43 & 0 & 0 & 0 \\
\hline 10 & LG 32.52 & 0 & 0 & 0 \\
\hline 11 & LG 30.238 & 0 & 0 & 0 \\
\hline 12 & LG 32.58 & 0 & 0 & 0 \\
\hline 13 & Laureen & 4 & 0 & 0 \\
\hline & LSD 0.05 & 0.6 & 0 & 0 \\
\hline
\end{tabular}

\subsubsection{Experiment II}

In the experiment, the varieties SY Cooky and NK Ravello showed no damage in any of the protection variants applied. The results are shown in Table 6.

Table 6. Sensitivity of two maize varieties to different herbicide variants.

\begin{tabular}{cccccc}
\hline \multicolumn{7}{c}{ Phytotoxicity (\%) } \\
\hline No. & Active Ingredient & Dose (L/ha) & Dose (g a.i./ha) & ZEAMX_SY Cooky & ZEAMX-NK Ravello \\
\hline 1 & Untreated * & - & - & 14 DAT & 14 DAT \\
\hline 2 & MCPA & 3 & 900 & 0 & 0 \\
\hline 3 & $\begin{array}{c}\text { MCPA + mepiquat } \\
\text { chloride }\end{array}$ & $3+1.3$ & $900+390$ & 0 & 0 \\
\hline 4 & 2,4 D + dicamba & $0.5+0.5$ & $300+240$ & 0 & 0 \\
\hline & LSD $_{0.05}$ & & 0 & 0 \\
\hline
\end{tabular}

* non-sprayed control applied for ZEAMX varieties—SY Cooky and NK Ravello, respectively ZEAMX-Zea mays L.

\subsubsection{Experiment III}

All herbicides showed high weed-killing effectiveness in relation to two weed species, Chenopodium album L. and self-seeding winter oilseed rape (Brassica napus L.). No statistically significant differences were found between the individual combinations. The highest herbicidal effectiveness in controlling both weed species was recorded for the mixture of 2,4-D + dicambachloride. The addition of mepiquat chloride to the composition of the spraying liquid did not affect the effectiveness of the herbicide containing MCPA (Figure 1). 


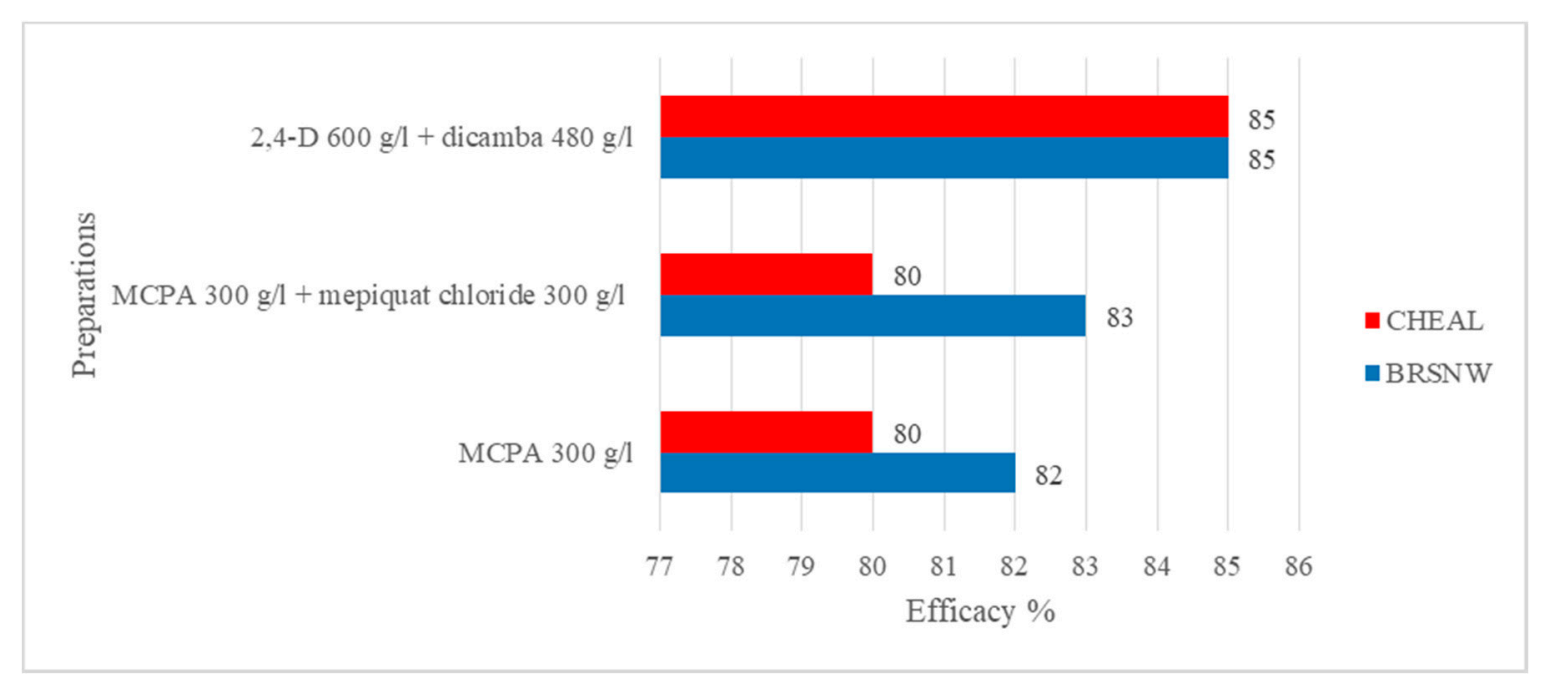

Figure 1. Evaluation of herbicide efficacy against Chenopodium album L., and Brassica napus L (no significant differences).

\subsection{Laboratory Experiments}

\subsubsection{Genetic Similarity of Varieties}

A total of 112 SSR markers were detected with the set of 30 SSR primers. The average number of alleles per locus was 3.73, ranging from 1 to 17. The size of PCR products ranged from 63 to $267 \mathrm{bp}$. The data were computed to estimate genetic similarity between studied five maize cultivars based on Nei and Li's coefficients. The highest genetic similarity (amounting to 0.719) was found between cultivars Delitop and NK Ravello, whereas the lowest genetic similarity $(0.310)$ was found for cv. NK Cooler and Drim (Table 7). The mean value of genetic similarity was 0.523 . The SSR markers data were used to group cultivars by the unweighted pair group method of arithmetic means (UPGMA) method. The relationships between cultivars are presented in the form of a dendrogram (Figure 2).

Table 7. Genetic similarity among the studied five cultivars of maize based on 112 SSR markers.

\begin{tabular}{cccccc}
\hline Cultivar & NK Cooler & Delitop & NK Ravello & SY Cooky & Drim \\
\hline NK Cooler & 1 & & & & \\
\hline Delitop & 0.478 & 1 & & & \\
\hline NK Ravello & 0.481 & 0.719 & 1 & & \\
\hline SY Cooky & 0.388 & 0.597 & 0.612 & 1 & \\
\hline Drim & 0.310 & 0.441 & 0.553 & 0.652 & 1 \\
\hline
\end{tabular}




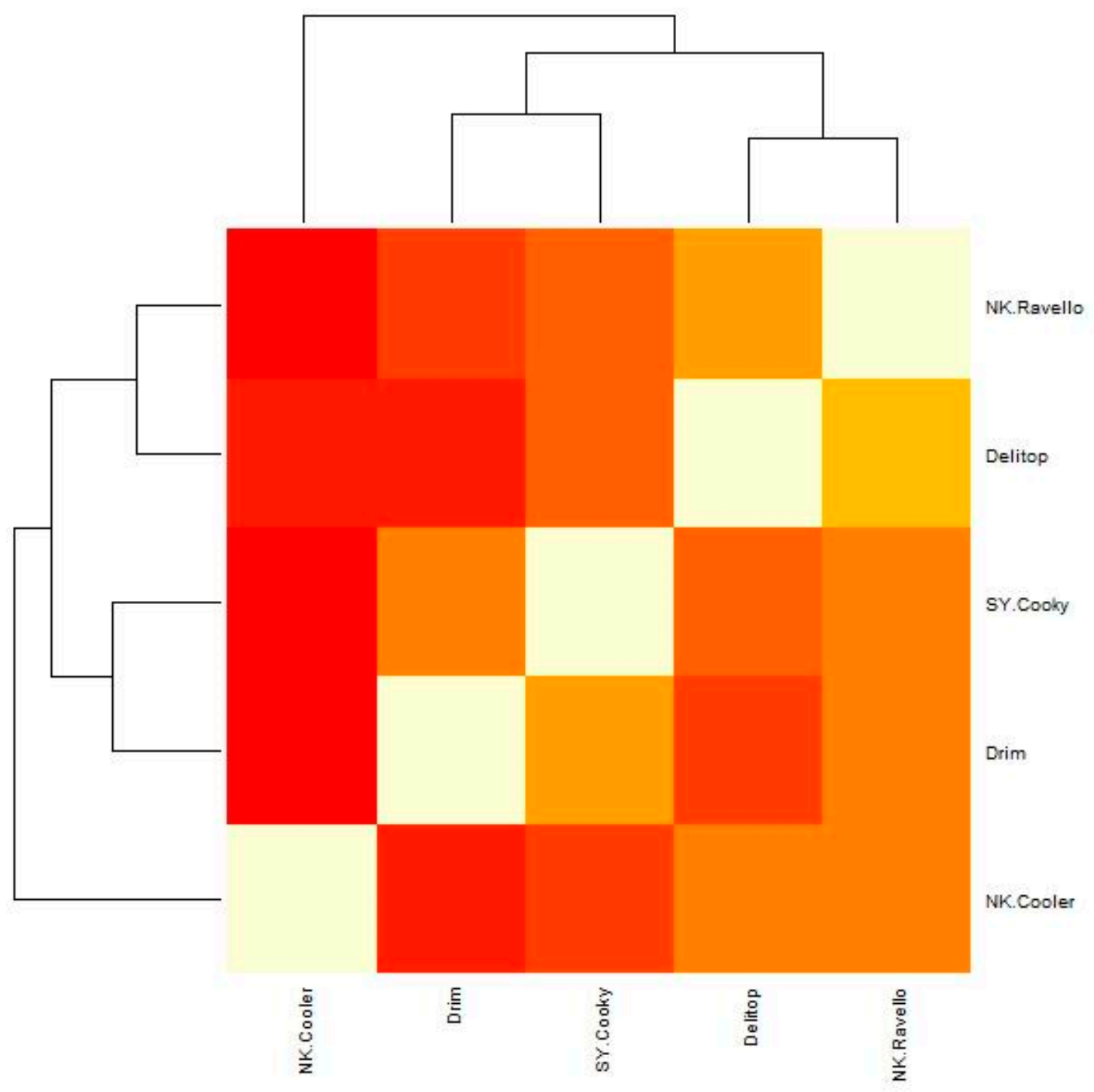

Figure 2. Heatmap of genetic similarity of five cultivars of maize constructed for 112 SSR markers. Cultivars were grouped hierarchically using the unweighted pair group method of arithmetic means (UPGMA).

\subsubsection{Identification of Fusarium Species}

Molecular analyses confirmed the morphological identification of 25 Fusarium isolates used in the experiment. PCR products from F. subglutinans, F. proliferatum, and F. verticillioides were $519 \mathrm{bp}, 526 \mathrm{bp}$, and $534 \mathrm{bp}$ in length, respectively. All isolates were tested with the species-specific primers VER 1/2 and PRO 1/2. From the $69 \%$ isolates, morphologically identified as F. verticillioides, $66 \%$ were identified using the VER $1 / 2$ primers, whereas $17 \%$ of isolates were morphologically identified as F. proliferatum, seven of which were identified using the PRO 1/2 primers.

\section{Discussion}

Factors determining the size and quality of maize yield involve climate and soil conditions, agrotechnics, including fertilization and plant protection, variety selection, plant density, and date of harvest [24]. According to Adamczyk [25], the amount and quality of the harvested maize was in $40 \%$ determined by agrotechnical factors, $30 \%$ climatic conditions, and $30 \%$ by correct selection of varieties. 
Individual varieties may react differently to different herbicides [26]. This has also been confirmed for maize [27]. Since the introduction of these plant varieties with different earliness (FAO) and genetic traits into cultivation, it has become important to determine their herbicide selectivity, as proven in numerous works on the reaction of varieties to chemical plant protection products [28,29].

Information contained in the works of other scientists indicated that the use of mesotrione could contribute to the occurrence of phytotoxicity on maize plantations, which, however, did not have a negative impact on yield [30,31]. In the conducted experiment, this substance contributed to the greatest damage to plants belonging to the varieties Kardona, SY Multitop, and Laureen. Maize plantations also showed signs of phytotoxicity after the application of herbicides belonging to the group of synthetic auxins and bromoxynil. For 2,4-D, damages were observed, such as leaf curling and stem bending and brittleness. On the other hand, yellow and brown leaf discoloration is an undesirable symptom of bromoxynil action [32]. In the tests carried out on all varieties in experiment I, transient symptoms of phytotoxicity were observed after the application of 2,4-D, while bromoxynil contributed to damages to plants of the varieties LG 30.275 and Laureen. In experiment II, however, herbicides from the group of growth regulators did not cause the phytotoxicity effect in the two varieties tested. No relationship was found between the genetic distance of maize varieties and their sensitivity to the applied herbicides. However, testing for herbicide selectivity is important for individual crop varieties. The condition for using the varietal progression of maize carried by maize seed is to recognize the susceptibility of cultivated varieties to herbicidal damage. It is also worth remembering that stress caused by herbicide damage can contribute to greater susceptibility of plants to diseases [33].

Chenopodium album L. is a common weed in maize plantations, and it can contribute to significant yield reduction [34]. Self-seeding oilseed rape can also be a problem in the cultivation of the discussed plant $[35,36]$. In experiment III, the tested herbicides showed high herbicidal effectiveness against Chenopodium album L. and Brassica napus L. All herbicide variants contributed to a high level of weed control. Similar results, i.e., high herbicidal effectiveness against Chenopodium album L. after MCPA application, were obtained by Majchrzak et al. [37]. Roskamp et al. [38] noted that the applied herbicides containing dicamba and 2,4-D successfully eliminated various weed species, among them Chenopodium album $\mathrm{L}$. The addition of mepiquat chloride did not affect the effectiveness of the selected herbicide. This is important from the point of view of the tank mixtures used in agricultural practice in plant protection products.

F. verticillioides was detected in most of the tested isolates. This species is one of the most common pathogens on maize plantations in the world [39]. F. proliferatum is another commonly occurring species [40]. Its presence was found in the tested samples. The presence of $F$. subglutinans was also found in the material subjected to the tests. This species is also considered an important pathogen appearing on maize plantations [41]. Such species composition of pathogens belonging to the genus Fusarium was also described by other scientists [23].

\section{Conclusions}

The variety is an important factor affecting the reaction of crop plants to the applied herbicides. The varieties used in the experiments showed different sensitivity to the applied herbicides. No relationship was found between the genetic similarity of individual maize varieties and their reaction to the applied herbicides. The applied herbicides were highly effective against weeds; the addition of mepiquat chloride did not affect the level of control of self-seeding oilseed rape and Chenopodium album L. In the tested samples, fungi from the genus Fusarium were found, which are often present in maize-F. subglutinans, F. proliferatum, and F. verticillioides. Effective weed control without phytotoxic effects of plant protection products, as well as properly carried out control against fungal pathogens, among which Fusarium ssp. plays a significant role, are factors that largely affect the level of maize yield.

Author Contributions: M.J. and Ł.S. conceived and designed the experiments; M.J., Ł.S., K.N., and P.S. performed the experiments and analyzed the data; J.B. performed statistical analysis; M.J., Ł.S., and M.G. wrote the paper, 
Ł.S., M.G., and P.S. prepared the references; P.S. revised the manuscript. All authors have read and agreed to the published version of the manuscript.

Funding: The paper was financed within the framework of the Ministry of Science and Higher Education program 'Regional Initiative of Excellence' in the years 2019-2022; Project No. 005/RID/2018/19.

Conflicts of Interest: The authors declare no conflicts of interest.

\section{References}

1. Owen, M.D.K. Diverse Approaches to Herbicide-Resistant Weed Management. Weed Sci. 2016, 64, 570-584. [CrossRef]

2. Hasanuzzaman, M.; Mohsin, S.M.; Borhannuddin Bhuyan, M.H.M.; Farha Bhuiyan, T.; Anee, T.I.; Awal, A.; Masud, C.; Nahar, K. Phytotoxicity, environmental and health hazards of herbicides: Challenges and ways forward. In Agrochemicals Detection, Treatment and Remediation. Pesticides and Chemical Fertilizers; Vara Prasad, M.N., Ed.; Butterworth Heinemann: Hyderabad, India, 2020; pp. 55-99.

3. Bountin, C.; Aya, K.L.; Carpenter, D.; Thomas, P.J.; Rowland, O. Phytotoxicity testing for herbicide 451 regulation: Shortcomings in relation to biodiversity and ecosystem services in agrarian systems. Sci. Total Environ. 2012, 415, 79-92. [CrossRef] [PubMed]

4. Grossmann, K. Auxin herbicides: Current status of mechanism and mode of action. Pest Manag. Sci. 2010, 66, 113-120. [CrossRef] [PubMed]

5. Vink, J.P.; Soltani, N.; Robinson, D.E.; Tardif, F.J.; Lawton, M.B.; Sikkema, P.H. Glyphosate-resistant giant ragweed (Ambrosia trifida) control in dicamba-tolerant soybean. Weed Technol. 2012, 26, 422-428. [CrossRef]

6. Peterson, M.A.; McMaster, S.A.; Riechers, D.E.; Skelton, J.; Stahlman, P.W. 2,4-D past, present, and future: A review. Weed Technol. 2016, 30, 303-345. [CrossRef]

7. Sutton, P.; Richards, C.; Buren, L.; Glasgow, L. Activity of mesotrione on resistant weeds in maize. Pest Manag. Sci. 2002, 58, 981-984. [CrossRef]

8. Moran, G.R. 4-Hydroxyphenylpyruvate dioxygenase. Arch. Biochem. Biophys. 2005, 433, 117-128. [CrossRef]

9. Ahrens, H.; Lange, G.; Müller, T.; Rosinger, C.; Willms, L.; van Almsick, A. 4-Hydroxyphenylpyruvate Dioxygenase Inhibitors in Combination with Safeners: Solutions for Modern and Sustainable Agriculture. Angew. Chem. Int. Ed. 2013, 52, 9388-9398. [CrossRef]

10. Mitchell, G.; Bartlett, D.W.; Fraser, T.E.M.; Hawkes, T.R.; Holt, D.C.; Townson, J.K.; Wichert, R.A. Mesotrione: A new selective herbicide for use in maize. Pest Manag. Sci. 2001, 57, 120-128. [CrossRef]

11. Abendroth, J.A.; Martin, A.R.; Roeth, F.W. Plant Response to Combinations of Mesotrione and Photosystem II Inhibitors. Weed Technol. 2006, 20, 267-274. [CrossRef]

12. Hess, F.D. Light-dependent herbicides: An overview. Weed Sci. 2000, 48, 160-170. [CrossRef]

13. Muhammad, K.; Irshad, A.; Haiqi, W.; Xiaorong, W.; Jing, X.; Tiening, L.; Ruixia, D.; Qingfang, H. Mepiquat chloride application increases lodging resistance of maize by enhancing stem physical strength and lignin biosynthesis. Field Crops Res. 2018, 224, 148-159.

14. Muthukumar, V.B.; Velayudham, K.; Thavaprakaash, N. Growth and Yield of Baby Corn (Zea mays L.) as Influenced by Plant Growth Regulators and Different Time of Nitrogen Application. Res. J. Agric. Biol. Sci. 2005, 1, 303-307.

15. Miziniak, W.; Matysiak, K. Interaction of herbicides with mepiquat chloride and prohexadione calcium in winter wheat. J. Plant Prot. Res. 2019, 59, 494-502.

16. Logrieco, A.; Mulé, G.; Moretti, A.; Bottalico, A. Toxigenic Fusarium species and mycotoxins associated with maize ear rot in Europe. Eur. J. Plant Pathol. 2002, 108, 597-609. [CrossRef]

17. Szabó, B.; Varga, M.; György, A.; Mesterházy, Á.; Tóth, B. Role of Fusarium species in mycotoxin contamination of maize. J. Agric. Ext. Rural Dev. 2016, 5, 104-108.

18. Nowosad, K.; Bocianowski, J.; Szulc, P. Analysis of molecular variance and genetic similarity between selected cultivars of maize (Zea mays L.) revealed by SSR markers. Fragm. Agron. 2017, 34, 134-144.

19. Available online: www.maizegdb.org (accessed on 25 May 2020).

20. Nei, M.; Li, W. Mathematical model for studying genetic variation in terms of restriction endonucleases. Proc. Natl. Acad. Sci. USA 1979, 76, 5269-5273. [CrossRef]

21. Leslie, J.F.; Summerell, B.A. The Fusarium Laboratory Manual; Blackwell Publishing Professional: Ames, IA, USA, 2006; p. 388. 
22. Gerlach, W.; Nirenberg, H. The Genus Fusarium: A Pictorial Atlas; Mitteilungen aus der Biologischen Bundesanstalt für Land-und Forstwirtschaft Berlin-Dahlem; Kommissionsverlag P. Parey: Berlin, Germany, 1982; p. 406.

23. Mulé, G.; Susca, A.; Stea, G.; Moretti, A. A species-specific PCR assay based on the calmodulin partial gene for identification of Fusarium varticillioides, F. proliferatum and F. subglutinans. Eur. J. Plant Pathol. 2004, 110, 495-502. [CrossRef]

24. Filipek-Mazur, B.; Lepiarczyk, A.; Tabak, M. Wpływ nawożenia azotem i siarką na plonowanie oraz skład chemiczny ziarna kukurydzy część II. Zawartość azotu i siarki. Fragm. Agron. 2013, 30, 29-35.

25. Adamczyk, J. Znaczenie doboru odmian w uprawie kukurydzy na ziarno i kiszonkę. Biul. Inf. Zoot. 2001, 39, 29-35.

26. Qasem, J.R. Herbicides applications: Problems and considerations. In Herbicides and Environment; Kortekamp, A., Ed.; InTech: London, UK, 2011; pp. 643-664.

27. Jhala, A.J.; Knezevic, S.Z.; Ganie, Z.A.; Singh, M. Integrated weed management in corn (Zea mays L.). In Recent Advances in Weed Management; Chauhan, B., Mahajan, G., Eds.; Springer: New York, NY, USA, 2014; pp. 177-196.

28. Rola, H. Oddziaływanie fitotoksyczne niektórych herbicydów na odmiany kukurydzy. Prog. Plant Prot. 2003, 43, 176-178.

29. Gołębiowska, H.; Rola, H. The influence of weather conditions on selectivity of sylfonylourea herbicides to the selected maize varieties. J. Plant Prot. Res. 2003, 43, 219-224.

30. Available online: www.regional.org.au/au/allelopathy/2005/2/7/2636_cornesd.htm (accessed on 25 May 2020).

31. Pannacci, E.; Covarelli, G. Efficacy of mesotrione used at reduced doses for post-emergence weed control in maize (Zea mays L.). Crop Prot. 2009, 28, 57-61. [CrossRef]

32. Clay, D.; Reitsma, K.D.; Clay, S. Best Management Practices for Corn Production in South Dakota; South Dakota State University, College of Agriculture and Biological Sciences, AgBio Communications Unit, Box 2218A: Brookings, SD, USA, 2009.

33. Keane, P.; Kerr, A. Factors affecting disease development. In Plant Pathogens and Plant Diseases; Brown, J.F., Ogle, H.J., Eds.; Rockvale Publishing: Armidale, Australia, 1997; pp. 287-298.

34. Redwitz, C.; Gerowitt, B. Welche Faktoren fördern das Auftreten von Chenopodium album auf norddeutschen Maisflächen? In Proceedings of the 26th German Conference on weed Biology an Weed Control, Braunschweig, Germany, 11-13 March 2014.

35. Weber, E.A.; Gruber, S.; Claupein, W. Emergence and performance of volunteer oilseed rape (Brassica napus) in different crops. Europ. J. Agron. 2014, 60, 33-40. [CrossRef]

36. Streit, B.; Rieger, S.B.; Stamp, P.; Richner, W. The effect of tillage intensity and time of herbicide application on weed communities and populations in maize in central Europe. Agric. Ecosyst. Environ. 2002, 92, 211-224. [CrossRef]

37. Majchrzak, L.; Idziak, R.; Pudełko, J.; Piechota, T.; Sobiech, Ł. Skuteczność i selektywność różnych soli MCPA do odchwaszczania jęczmienia jarego. Fragm. Agron. 2012, 29, 120-126.

38. Roskamp, J.M.; Chahal, G.S.; Johnson, W.G. The Effect of Cations and Ammonium Sulfate on the Efficacy of Dicamba and 2,4-D. Weed Technol. 2013, 27, 72-77. [CrossRef]

39. Baghbani, F.; Lotfi, R.; Moharramnejad, S.; Bandehagh, A.; Roostaei, M.; Rastogi, A.; Kalaji, H.M. Impact of Fusarium verticillioides on chlorophyll fluorescence parameters of two maize lines. Eur. J. Plant Pathol. 2019, 154, 337-346. [CrossRef]

40. Jurado, M.; Marín, P.; Callejas, C.; Moretti, A.; Vázquez, C.; González-Jaén, M.T. Genetic variability and Fumonisin production by Fusarium proliferatum. Food Microbiol. 2010, 27, 50-57. [CrossRef]

41. Scauflaire, J.; Gourgue, M.; Munaut, F. Fusarium temperatum sp. nov. from maize, an emergent species closely related to Fusarium subglutinans. Mycologia 2011, 103, 586-597. [CrossRef] [PubMed]

(C) 2020 by the authors. Licensee MDPI, Basel, Switzerland. This article is an open access article distributed under the terms and conditions of the Creative Commons Attribution (CC BY) license (http://creativecommons.org/licenses/by/4.0/). 